\title{
Analogues of the natural product Sinefungin as potent inhibitors of EHMT1 and EHMT2
}

\author{
Kanchan Devkota ${ }^{1,2^{*}}$, Brian Lohse ${ }^{2}$, Qing Liư ${ }^{3}$, Ming-Wei Wang ${ }^{3}$, Jens Berthelsen ${ }^{1}$, Rasmus Prætorius Clausen² \\ From Epigenetics \& Chromatin: Interactions and processes \\ Boston, MA, USA. 11-13 March 2013
}

\section{Background}

Protein Lysine methyltransferases (PKMTs) are group of histone modifiers that are responsible for the transfer of one to three methyl groups from $S$-adenosyl-L-methionine (AdoMet) to the $\varepsilon$-amino group of the target lysine residues in histones[1] and some non-histone targets[2]. To date more than 50 PKMTs have been identified and EHMT1 (Euchromatic Histone Methyltransferase 1, GLP, G9a like proteins) and EHMT2 (Euchromatic Histone Methyltranferase 2, G9a) are amongst the most studied ones. Genetic variations of EHMT1/2 have been associated with human diseases such as cancer, inflammatory diseases and neuro-generative disorders. As a consequence, there has been a growing interest to identify potent inhibitors of these enzymes.

\section{Materials and methods}

We employed Sinefungin as a lead structure for the design and synthesis of a series of methyltransferase inhibitors and tested them for inhibition of EHMT1/2. The $\alpha$-amino acid moiety of Sinefungin was exchanged to obtain two different series of compounds- one with the additional amino group and one without amino group. Screening of compounds were done by using a FRET-based LANCE ultra G9a histone H3-Lysine N-methyltransferase assay[3] that measures the dimethylation of a biotinylated histone H3 (1-21) peptide at lysine 9.

\section{Results}

A series of analogues of the natural product Sinefungin was designed and synthesized, and probed for their ability to inhibit EHMT1 and EHMT2. This led to a highly potent inhibitor $4 \mathrm{~d}$ with a $\mathrm{K}_{\mathrm{i}}$ of $5 \mathrm{nM}$ at EHMT1 and $24 \mathrm{nM}$ at EHMT2. There was variation in the activity of

\footnotetext{
${ }^{1}$ The NNF Center for Protein Research, University of Copenhagen, Blegdamsvej 3B, DK-2200, Copenhagen, Denmark

Full list of author information is available at the end of the article
}

the compounds and most of the compounds displayed little inhibition.

\section{Conclusion}

Here we exchanged the $\alpha$-amino acid moiety and demonstrated that it is not essential for inhibitory activity at EHMT1/2. Our results indicate that these scaffolds upon further modifications can lead to selective, potent inhibitors of EHMTs and possibly other PKMTs.

\section{Acknowledgements}

We are thankful to Novo Nordisk Foundation Center for Protein Research and Department of Health Sciences, University of Copenhagen for the Ph.D. fellowship, Dr. Thomas Frimurer for valuable inputs in designing the analogues, Ms. Huili Lu and Ms. Jie Zhang for technical assistance, the Danish Cancer Society, the University of Copenhagen Programme of Excellence and the Ministry of Science and Technology of China (2009ZX09302-001, 2012ZX09304011 and 2013ZX09507002) for grant support.

\section{Author details}

${ }^{1}$ The NNF Center for Protein Research, University of Copenhagen, Blegdamsvej 3B, DK-2200, Copenhagen, Denmark. ²Department of Drug Design and Pharmacology, University of Copenhagen, Universitatsparken 2, DK-2100, Copenhagen, Denmark. ${ }^{3}$ The National Center for Drug Screening and the Key Laboratory of Receptor Research, Shanghai Institute of Materia Medica, Chinese Academy of Sciences, Shanghai 201203, China.

Published: 8 April 2013

\section{References}

1. Rea S, Eisenhaber F, O'Carroll D, Strahl BD, Sun ZW, Schmid M, Opravil S, Mechtler K, Ponting CP, Allis CD, Jenuwein T: Regulation of chromatin structure by site-specific histone H3 methyltransferases. Nature 2000, 406:593-599.

2. Huang J, Berger SL: The emerging field of non-histone proteins. Current opinion Genet Dev 2008, 152-158.

3. Rouleau N, Pedro L, Gauthier N, Labonté A, Paquet V, Rodenbrock A, Roy M, Marcil A, Plante $H$, Beaudet L, Rodriguez-Suarez R: Development of HighThroughput Assays to Study Histone H3K4 Methyltransferases \& H3K9 Methyl- and Acetyltransferases. Biotechniques Poster Hall Fall 2011.

4. Zheng WH, Ibáñez G, Wu H, Blum G, Zeng H, Dong AP, Li FL, Hajian T, Allali-Hassani A, Amaya MF, Siarheyeva L, Yu WY, Brown PJ, Schapira M, Vedadi M, Min JR, Luo MK: Sinefungin Derivatives as Inhibitors and 
Structure Probes of Protein Lysine Methyltransferase SETD2. J Am Chem Soc 2012, 134(43):18004-18014.

doi:10.1186/1756-8935-6-S1-P112

Cite this article as: Devkota et al: Analogues of the natural product

Sinefungin as potent inhibitors of EHMT1 and EHMT2. Epigentics \&

Chromatin 2013 6(Suppl 1):P112.
Submit your next manuscript to BioMed Central and take full advantage of:

- Convenient online submission

- Thorough peer review

- No space constraints or color figure charges

- Immediate publication on acceptance

- Inclusion in PubMed, CAS, Scopus and Google Scholar

- Research which is freely available for redistribution

Submit your manuscript at www.biomedcentral.com/submit
Ciomed Central 